\title{
THE ROLE OF FAT MASS AND OBESITY ASSOCIATED GENE (FTO) IN SATIETY AND BINGE EATING DISORDER
}

\author{
Mariana Laitano Dias de Castro ${ }^{1,2}$, Jaqueline Driemeyer Correia Horvath ${ }^{1,2}$, \\ Natalia Luiza Kops ${ }^{3}$, Rogério Friedman ${ }^{1,2,4}$
}

Clin Biomed Res. 2015;35(4):178-183

1 Programa de Pós-graduação em Endocrinologia, Universidade Federal do Rio Grande do Sul (UFRGS). Porto Alegre, RS, Brazil.

2 Serviço de Endocrinologia, Hospital de Clínicas de Porto Alegre (HCPA). Porto Alegre, RS, Brazil.

3 Curso de Nutrição, Faculdade de Medicina, Universidade Federal do Rio Grande do Sul (UFRGS). Porto Alegre, RS, Brazil.

4 Departamento de Medicina Interna, Faculdade de Medicina, Universidade Federal do Rio Grande do Sul (UFRGS). Porto Alegre, RS, Brazil.

Corresponding author: Rogério Friedman E-mail: rogeriofriedman@gmail.com Hospital de Clínicas de Porto Alegre Serviço de Endocrinologia Rua Ramiro Barcelos, 2350. 90035-903, Porto Alegre, RS, Brazil.

\section{ABSTRACT}

Obesity is a major health problem and one of the biggest predictors of the development of chronic diseases. Variations in the Fat mass and obesity associated gene (FTO) have been shown to associate strongly with obesity. Among patients with severe obesity, there is a subpopulation that presents an eating disorder known as Binge Eating Disorder. Because of its expression in the hypothalamus, FTO could be associated with modulation of satiety and, perhaps, play a role in the genesis of BED, contributing to severe obesity. A search in PubMed was carried out with the following terms: Morbid Obesity AND FTO, FTO AND Satiety Response, Binge Eating Disorder AND FTO. No restriction on the date of publication, language or type of design was applied. Sixteen articles were found. Twelve were related to FTO and grade III obesity, and three were related to FTO and satiety. Ten studies were excluded. Thus, six articles were evaluated in this review. The scarce literature limits further conclusions about the potential impact of the associations with FTO in the treatment of obesity, but all articles included in this revision show association with at least one SNP of FTO. Further studies are required to clarify these associations, especially in relation to rs9939609 (A/T), because, up to this moment, it seems to be the one variant with greatest impact on obesity in humans.

Keywords: Obesity; FTO; satiety

Obesity is one of the main health problems in the 21st Century. It is an established risk factor for conditions such as Type 2 diabetes mellitus, cardiovascular disease and cancer $^{1}$.

The prevalence of overweight and obesity has doubled in the last thirty years. In Brazil, a 2008/2009 survey of the Ministry of Health showed that $8.9 \%$ of the population is obese. In the South of the country, $10.1 \%$ of the male population and $15.1 \%$ of the female population is obese. Brazilian estimates point out that, in the year 2025, the country will have the fifth largest prevalence of obesity worldwide ${ }^{2}$. Clinically, obesity is diagnosed in the presence of a body mass index (BMI) equal to or higher than $30 \mathrm{~kg} / \mathrm{m}^{2}$, in adults ${ }^{3}$.

Recent studies show associations of BMI with body fat and with the the "Fat mass and obesity associated" (FTO) gene ${ }^{4}$, located in chromosome $16 q 12.2^{5,6}$. Variations in this gene (single-nucleotide polymorphisms - SNPs) were strongly associated with obesity and diabetes mellitus ${ }^{7}$. The association of FTO with human obesity has been shown in caucasian populations studies ${ }^{8-11}$. Besides the association with BMI and higher risk for overweight and obesity, SNPs in FTO have been associated with obesity and body weight ${ }^{5,8,11}$, leptin levels ${ }^{11}$, subcutaneous fat ${ }^{5,8}$, fat mass $\mathrm{s}^{5,8,11}$ and waist circumference ${ }^{11}$.

The messenger RNA (mRNA) of FTO is expressed in the hypothalamus ${ }^{12}$, an area that is connected with appetite regulation; in rodents, FTO mRNA expression in the hypothalamus is modulated by acute food deprivation ${ }^{13}$. One recent study, in human adults, has found differences in the caloric intake, but no difference in the energy expenditure, showing that the FTO genotypes affect body weight mostly through caloric intake ${ }^{14}$. 
Recent research shows that, among obese subjects, there is a subpopulation with similar characteristics that does not respond to the usual behavioral treatment for weight loss. This group presents an eating disorder known as Binge Eating Disorder (BED) ${ }^{15}$.

Binge eating is characterized by a very high intake of food within two hours, followed by a feeling of loss of control of what and how much it is eaten. According to DSM IV-TR, BED is diagnosed when episodes happen at least twice a week, for six months, associated to some characteristics of loss of control, and are not followed by compensatory behaviors (such as vomiting or use of laxatives) ${ }^{16}$.

Patient medical records indicate that they have an early onset of obesity, high BMls, and poor response to dietary treatment; they also spend more time involved with their diets ${ }^{17}$. An estimated frequency of $5-30 \%$ (and in one extreme report, $50 \%$ ) of BED among obese patients that look for help has been reported. In the general population, the prevalence of BED is of $2-3 \%$. In Brazil, a prevalence of $15-22 \%$ has been reported in patients that look for help for weight loss ${ }^{18}$.

Due to its expression in the hypothalamus, FTO may be associated with satiety modulation and, consequently play a role in the genesis of BED, contributing to severe obesity and its complications.

This article sought to report the current knowledge on the association of polymorphisms of FTO with satiety in obese individuals.

\section{METHODS}

We conducted a search in Pubmed (National Center for Biotechnology Information, U.S. National Library of Medicine), with the following associated MESH terms: Obesity Morbid AND FTO, Satiety Response AND FTO, Binge eating disorder AND FTO. We set no restrictions as to the date of publication, language, age of the subjects in each study, or type of design.

The search and analysis strategies were of a structured review.

Were excluded from this review: studies that encompassed items not related to overweight and/or obesity, and those with patients who had undergone bariatric surgery or other surgery that could interfere with the gastrointestinal tract. Only studies with human subjects were included.

\section{RESULTS}

A total of 16 articles were found; of these, 12 were related to FTO and grade III obesity; 3 to FTO and satiety; and 1 to BED and FTO. Of the studies that correlated FTO and obesity, seven were excluded because the subjects had undergone bariatric surgery, and two were experimental animal studies. The article related to BED was excluded because it was in low-weight patients. Thus, 6 articles were evaluated in this review, as illustrated Figure 1: 3 case-control studies; 1 review, 1 cross-sectional study and 1 brief communication. All of the case-control studies looked for the association between the genes connected to

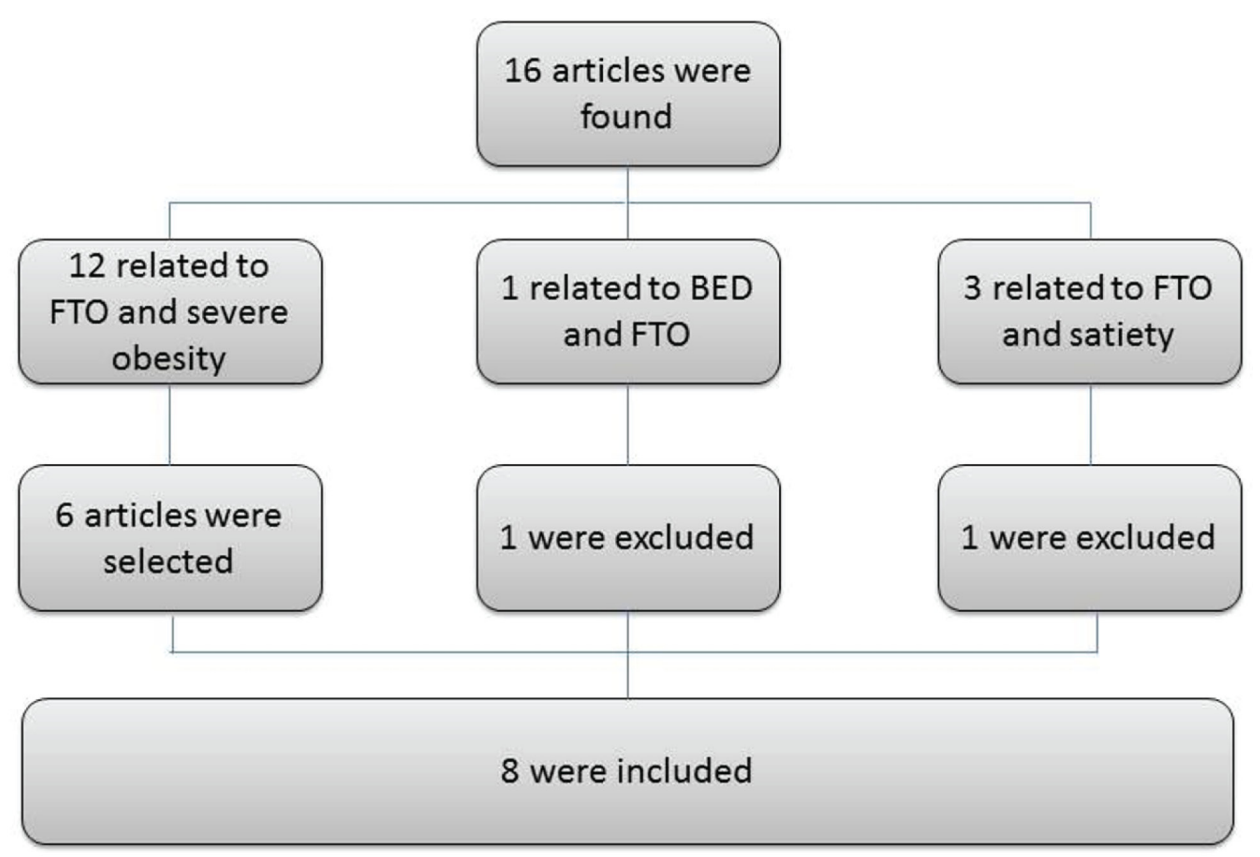

Figure 1: Article selection flowchart. 
Table 1: Association of Obesity and FTO polymorphism.

\begin{tabular}{llll}
\hline \multicolumn{1}{c}{$\begin{array}{c}\text { Author/Year } \\
\text { Journal/Qualis }\end{array}$} & \multicolumn{1}{c}{ Population } & \multicolumn{1}{c}{ Objetive } & \multicolumn{1}{c}{ Results } \\
\hline R Arlen Price & Women, BMI $>35 \mathrm{~kg} / \mathrm{m}^{2}$ & Examine SNPs (rs1421085, & There was association of \\
$\mathbf{( 2 0 0 8 )}^{19}$, BMC & (cases) Women, BMl <25kg/ & $\begin{array}{l}\text { rs17817449, rs9939609) to } \\
\text { debesity in all SNPs, the }\end{array}$ \\
Medical Genetics & $\mathrm{m}^{2}$ (controls) & FTO can be distinguished & $\begin{array}{l}\text { largest association observed } \\
\text { with rs1421085 }\end{array}$
\end{tabular}
between cases of extreme obesity and normal weight control

$\begin{array}{ll}\begin{array}{l}\text { R. Attaoua }(2009)^{20}, \\ \text { Diabetes \& } \\ \text { Metabolism }\end{array} & \begin{array}{l}\text { Thin women x obese women, } \\ \text { all received three diets and } \\ \text { after each diet there was } \\ \text { blood collection. GTT for } \\ \text { obese women }\end{array} \\ \begin{array}{ll}\text { David Meyre } & \text { Kids with obese Family, kids } \\ (\mathbf{2 0 0 9})^{21}, \text { Nature } & \text { with normal weight, thin } \\ \text { Genetics } & \text { adults, morbid obese adults }\end{array}\end{array}$

Raquel RodríguezLópez (2010) ${ }^{22}$, Endocrinologia y Nutrición
Patients with obesity before 16 , patients with phenotype and Family history of obesity
Investigate genetic association of FTO in obese women in the presence of IRS-2

Association of early onset genome (6 year old kids) and obese individuals, compared with individuals of the same age and normal weight

Evaluate the association of variation of FTO gene, based on SNP rs1861868 and rs9939609, with hereditary predisposition to suffer from morbid obesity

FTO: Fat Mass and Obesity associated, BMI: Body Mass Index, IRS-2: Insulin Receptor - 2, GTT: glucose tolerance test.

FTO and obesity. These articles described control groups of non-obese patients and obese patients (obesity level II and III). In the three articles, SNPs of FTO (rs1421085, rs1861868, rs9939609, rs17817449) were studied. In the study of Attaoua et al., a dietary intervention was carried out in order to provide the same nutritional environment. All studies showed associations between obesity and polymorphisms of FTO (table 1) $)^{19,20,22}$.

The study by Meyre et al., shows gene associations (including FTO) in two life stages: childhood and adult obesity; it tested these associations in three scenarios: childhood obesity only, adult and childhood obesity, and adult obesity only. The study highlights the importance of these associations showing that obesity in childhood and adult life share the same genetic architecture ${ }^{21}$.

The study by den Hoed et al. evaluated individuals with an average BMI of $25 \mathrm{~kg} / \mathrm{m}^{2}$, who received balanced and standardized meals (27\% protein, $45 \%$ carbohydrates, and $28 \%$ fat). After the test meals, hunger and satiety were evaluated through visual scales. In this article, five different SNPS were studied; one was FTO rs9939609. The authors found an association between the FTO rs9939609 polymorphism, lower satiety and lower postprandial hunger reduction ${ }^{23}$.

The review article examined genes that contribute to obesity and eating behaviors in children and adolescents - FTO, PPARG and MC4R. The most frequent FTO SNP would be rs9939609, as seen in studies relating $\mathrm{BMI}$ and body fat to the SNP children and adolescents. A small number of studies conducted in children measured the indirect intake of energy associated with the FTO and confirmed the higher risk of obesity due to reduced satiety, preference for energy dense food and not for energy expenditure as suggested by the literature ${ }^{24}$.

\section{DISCUSSION}

The present review shows how scarce are studies on FTO when associated with morbid obesity. In total only four SNPs in FTO were studied and not all showed positive associations. Of 4 studies that examined rs9939609, only one found association with obesity. Three studies examined rs1421085; one found an association with obesity and in one there was a correlated with insulin resistance ${ }^{19-22}$.

Price et al. found an association between obesity and several SNPs; among them, FTO rs1421085 showed the strongest association. This study included 
only women, Attaoua et al. also studied only females and found, besides the association with obesity, a correlation of rs1421085 with insulin resistance. The relation of FTO with insulin resistance was also reported by Cecil 20,24 .

The most studied SNP in FTO is rs9939609. Although just one study found an association with obesity in this review, there are in previous studies a description of decreased response to satiety in children and adolescents when rs9939609 is present, confirmed in other studies ${ }^{25-28}$. As Cecil, Frayling et al. also identified, rs9939609 carries an association with a higher Body Mass Index (BMI) in children and adults ${ }^{29}$.

In individuals with normal weight or overweight, den Hoed found a variable, but significant, association between rs9939609 and postprandial response of hunger and satiety ${ }^{23}$. These data suggest that the rs9939609 polymorphism is a predisposing factor to weight gain, but not mandatory.

Astudy related in a Spanish population demonstrated a relation of rs9939609 with severe obesity in childhood. Individuals with two SNPs (rs1861868 and rs9939609) had a $3.03 \%$ greater chance of developing severe obesity in adulthood. The impact of this and other eventual combinations of SNPs has not been properly evaluated to date ${ }^{22}$.

On the other hand, Liu et al. have not found associations of FTO rs9939609 with the caloric intake of the subjects in their review paper ${ }^{30}$. Nevertheless, this study did show a correlation between satiety and the FTO rs9939609. Being a non-systematic review, Liu's findings have to be weighed in view of the obvious limitation.

Women are the largest population with overweight and obesity in Brazil'; this fact happens in most countries. In a study conducted in 2009 , Cornes et al. analyzed rs9939609 and found an association with BMI in men and women, but with a stronger association in women ${ }^{4}$.
We notice that at different stages of life (childhood and adulthood) the association of FTO with obesity is similar. Meyere et al. confirm that obesity in both stages of life has the same genetics ${ }^{21}$.

We know the association of FTO with possible weight gain and increased BMI, waist circumference and insulin resistance, but we do not know where this influence begins and how FTO can be used to prevent obesity. Larder et al. reviewed studies of FTO in animal models and cell studies, and found no direct association with obesity-related mechanisms. There are still missing data to enable us to explain these relationships ${ }^{31}$.

All studies included in this review found positive associations between the FTO (and its various SNPs) and satiety and obesity. Unfortunately, the scarce literature limits further conclusions; the association exists, but it is not yet clear what real importance it carries to the problem of obesity, its mechanisms particularly appetite modulation - and, eventually, its treatment.

FTO rs9939609 seems to be the one SNP with the greatest impact on obesity, it most likely influences body mass through some interference with satiety, but there are no data as to a clear relation of FTO with eating disorders. Further studies in humans will have to be designed and carried out in order to clarify this subject.

\section{Acknowledgements}

This study was supported by Fundo de Incentivo à Pesquisa e Eventos do Hospital de Clínicas de Porto Alegre (FIPE-HCPA), Conselho Nacional de Desenvolvimento Científico e Tecnológico (CNPq) and Coordenação de Aperfeiçoamento de Pessoal de Nível Superior (CAPES).

\section{Conflicts of interest}

The authors declare no conflicts of interest.

\section{REFERENCES}

1. Zabena C, González-Sánchez JL, Martínez-Larrad MT, Torres-García A, Alvarez-Fernández-Represa J, Corbatón-Anchuelo A, et al. The FTO obesity gene. Genotyping and gene expression analysis in morbidly obese patients. Obes Surg. 2009;19(1):8795. http://dx.doi.org/10.1007/s11695008-9727-0. PMid:18855084

2. Instituto Brasileiro de Geografia e Estatística - IBGE. Pesquisa de Orçamentos Familiares 2008-2009:
Antropometria e Estado Nutricional de Crianças, adolescentes e Adultos no Brasil. Rio de Janeiro: IBGE; 2010.

3. Ogden CL, Yanovski SZ, Carroll $\mathrm{MD}$, Flegal KM. The epidemiology of obesity. Gastroenterology. 2007;132(6):2087-102. http://dx.doi. org/10.1053/j.gastro.2007.03.052. PMid:17498505.

4. Cornes BK, Lind PA, Medland SE, Montgomery GW, Nyholt DR, Martin
NG. Replication of the association of commoom rs9939609 variant of FTO with increased BMI in an Australian adult twin population but no evidence for gene by environment ( $\mathrm{GxE}$ ) interaction. Int J Obes. 2009;33(1):759. http://dx.doi.org/10.1038/ ijo.2008.223. PMid:19030008.

5. Monteiro CA, Conde WL. A tendência secular da obesidade segundo estratos sociais: nordeste e sudeste do Brasil, 1975-1989-1997. Arq Bras 
Endocrinol Metab. 1999;43(3):18694. http://dx.doi.org/10.1590/S000427301999000300004.

6. Sposito AC, Caramelli B, Fonseca FA, Bertolami MC, Afiune A No, Souza AD, et al. IV Brazilian Guideline for Dyslipidemia and Atherosclerosis prevention: Department of Atherosclerosis of Brazilian Society of Cardiology. Arq Bras Cardiol. 2007;88(supl I):2-19. http://dx.doi.org/10.1590/ S0066-782X2007000700002. PMid:17515982.

7. Mozaffari H, Nabaei B. Obesity and related risk factors. Indian J Pediatr. 2007;74(3):265-7. http://dx.doi. org/10.1007/s12098-007-0041-y. PMid:17401265.

8. Gulati S, Saxena A. Study of lipid profile in children of patients with premature coronary artery disease. Indian Pediatr. 2003;40(6):556-60. PMid:12824666.

9. Françoso La, Coates V. Pathological evidence of the beginning of atherosclerosis. Arq Bras Cardiol. 2002;78(1):137-42.

10. Al-shehri S, Saleh ZA, Salama MM, Hassan YM. Prevalence of hyperlipidemia among Saudi school children in Riyadh. Ann Saudi Med. 2004;24(1):6-8. PMid:15310005.

11. Gama SR, Carvalho MS, Chaves CRMM. Prevalência em crianças de fatores de risco para as doenças cardiovasculares. Cad. Saúde Pública. 2007;23(9):2239-45. http://dx.doi.org/10.1590/S0102311X2007000900032.

12. Keith S, Redden DT, Katzmarzyk PT, Boggiano MM, Hanlon EC, Benca RM, et al. Putative contributors to the secular increase in obesity: exploring the roads less traveled. Int J Obes. 2006;30(11):1585-94. http:// dx.doi.org/10.1038/sj.ijo.0803326. PMid:16801930.

13. Heymsfield SB, Reitman ML. Obesity: genomics and postgenomics. N Engl J Med. 2008;358(22):2417-8. http:// dx.doi.org/10.1056/NEJMbkrev59421.

14. Speakman JR, Rance KA, Johnstone AM. Polymorphisms of the FTO gene are associated with variation in energy intake, but not energy expenditure. Obesity. 2008;16(8):1691-5. http:// dx.doi.org/10.1038/oby.2008.318.

15. Otto AFN. Obesidade e Transtorno da Compulsão Alimentar (TCAP): um estudo sobre a dinâmica familiar do paciente [thesis]. Brasília: Universidade Católica de Brasília; 2007.

16. American Psychiatric Association. DSM-IV-TR: diagnostic and statistical manual of mental disorders. 4th ed. Washington: American Psychiatric Publishing; 1994.

17. Souza NPP, Oliveira MRM, Motta DG. Transtorno de compulsão alimentar periódica em obesos sob tratamento ou não. Saúde Rev. 2006; 8(19):21-6.

18. Petribu K, Ribeiro ES, Oliveira FMF, Braz CIA, Gomes MLM, Araujo DE, et al. Transtorno da compulsão alimentar periódica em uma população de obesos mórbidos candidatos a cirurgia bariátrica do Hospital Universitário Oswaldo Cruz, em Recife - PE. Arq Bras Endocrinol Metab. 2006;50(5):901-8 http://dx.doi.org/10.1590/S000427302006000500011.

19. Price RA, Li WD, Zhao H. FTO gene SNPs associated with extreme obesity in cases, controls and extremely discordant sister pairs. BMC Med Genet. 2008;9(1):4. http:// dx.doi.org/10.1186/1471-2350-9-4 . PMid:18218107.

20. Attaoua R, Ait El Mkadem S, Lautier C, Kaouache S, Renard E, Brun JF, et al. Association of the FTO gene with obesity and the metabolic syndrome is independent of the IRS-2 gene in the female population of Southern France. Diabetes Metab. 2009;35(6):47683. http://dx.doi.org/10.1016/j. diabet.2009.07.002. PMid:19818665.

21. Meyre D, Delplanque J, Chèvre JC, Lecoeur C, Lobbens S, Gallina S, et al. Genome-wide association study for early-onset and morbid adult obesity identifies threes new risk loci in European Population. Nat Genet. 2009;41(2):157-9. http://dx.doi. org/10.1038/ng.301. PMid:19151714.

22. Rodríguez-López R, González-Carpio M, Serrano MV, Torres G, García de Cáceres MT, Herrera T, et al. Associación de polimorfismos en el gen FTO con obesidad mórbida em población extremeña. Endocrinol Nutr. 2010;57(5):203-9. http://dx.doi. org/10.1016/j.endonu.2010.03.002. PMid:20418190.

23. den Hoed M, Westerterp-Plantenga MS, Bouwman FG, Mariman EC, Westerterp KR. Postprandial responses in hunger and satiety are associated with the rs9939609 single nucleotide polymorphism in FTO. Am J Clin Nutr. 2009;90(5):1426-32. http:// dx.doi.org/10.3945/ajen.2009.28053. PMid:19793853.

24. Cecil J, Dalton M, Finlayson G, Blundell J, Hetherington M, Palmer C. Obesity and eating behavior in children and adolescents: Contribution of commom gene polymorphisms. Int Rev Psychiatry. 2012;24(3):200-10. http://dx.doi.org/10.3109/09540261.20 12.685056. PMid:22724641.

25. Hardy R, Wills AK, Wong A, Elks CE, Wareham NJ, Loos RJ, et al. Life course variations in the associations between FTO and MC4R gene variants and body size. Hum Mol Genet. 2010;191(3):545-52. http:// dx.doi.org/10.1093/hmg/ddp504. PMid:19880856.

26. Haworth CM, Butcher LM, Docherty SJ, Wardle J, Plomin R. No evidence for association between BMI and 10 candidate genes at ages 4, 7 and 10 in a large UK sample twins. BMG Medical Genetics. 2008;9(1):12. http:// dx.doi.org/10.1186/1471-2350-9-12. PMid:18304332.

27. Rzehak P, Scherag A, Grallert H, Sausenthaler S, Koletzko S, Bauer CP, et al.. Associations between BMI and the FTO gene are age dependent: Results from the GINI and LISA birth cohort studies up to age 6 years. Obes Facts. 2010;3(3):173-80. http:// dx.doi.org/10.1159/000314612. PMid:20616607.

28. Sovio U, Mook-Kanamori DO, Warrington NM, Lawrence R, Briollais L, Palmer CN, et al. Association between common variation at the FTO locus and changes in body mass index from infancy to late childhood: the complex nature of genetic association through growth and development. PLoS Genet. 2011;7(2):e1001307. http://dx.doi.org/10.1371/journal. pgen.1001307. PMid:21379325.

29. Frayling TM, Timpson NJ, Weedon $M N$, Zeggini E, Freathy RM, Lindgren $\mathrm{CM}$, et al. A common variant in the FTO gene is associated with body mass index and predisposes to childhood and adult obesity. Science. 2007;316(5826):889-94. PMID: 17434869 .

30. Liu G, Zhu H, Lagou V, Gutin B, Stallmann-Jorgensen IS, Treiber FA, et al. FTO variant rs9939609 is associated with body mass 
Fat mass and obesity associated gene and binge eating disorder

index and waist circumference,

but not with energy intake or

physical activity in European- and

African-American youth. BMC Med
Genet. 2010;11(1):57. http://dx.doi. org/10.1186/1471-2350-11-57.

PMid:20377915.
31. Larder R, Cheung MK, Tung YC, Yeo GS, Coll AP. Where to go with FTO? Trends Endocrinol Metab. 2011;22(2):53-9.

Received: Oct 11, 2015 Accepted: Dec 01, 2015 